Distribution and Demography of Coastal Cactus Wrens (Campylorhynchus brunneicapillus) in Southern San Diego County, California-2020 Data Summary

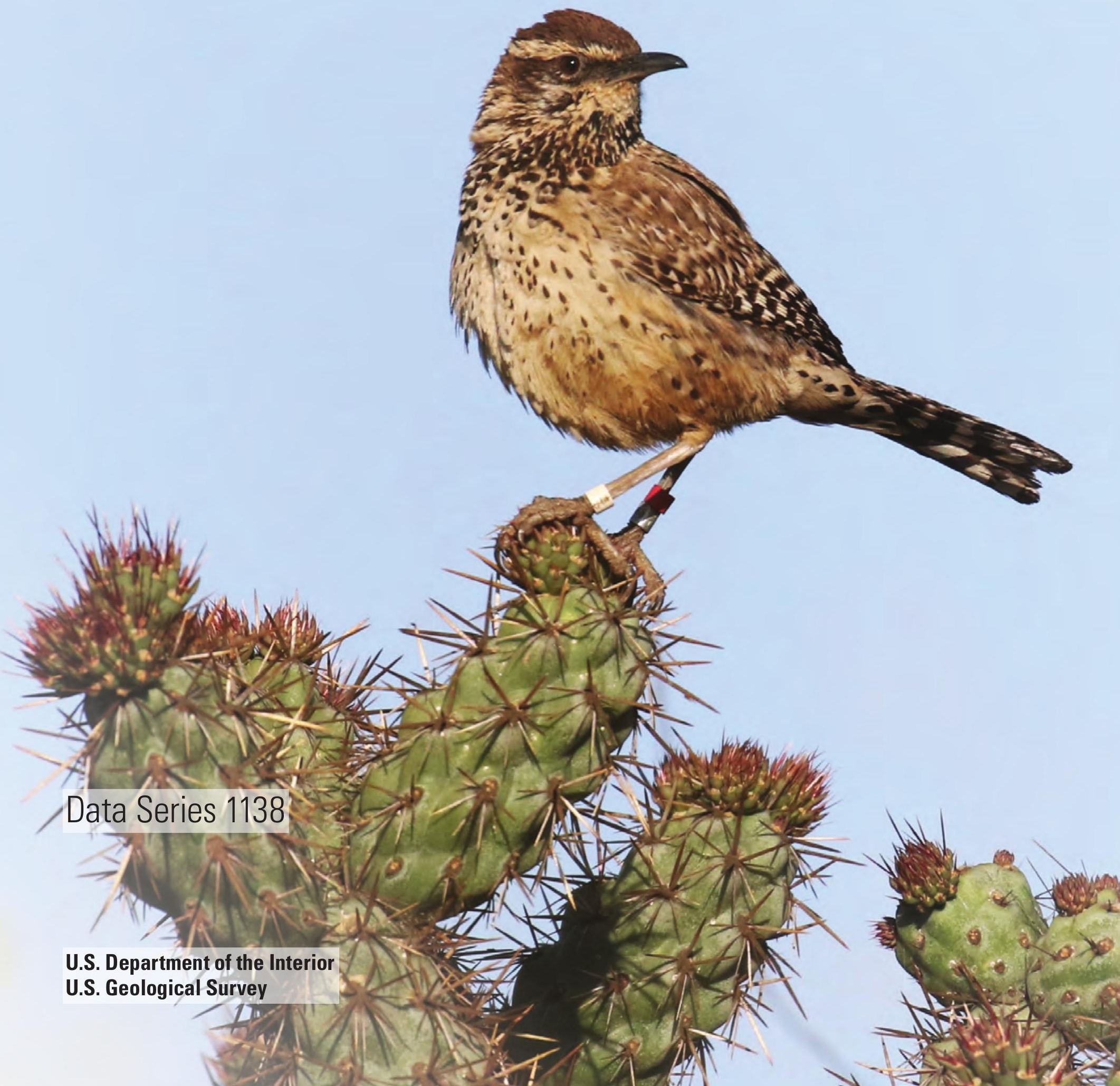


Cover. Photograph showing Coastal Cactus Wren (Campylorhynchus brunneicapillus). Photograph by Suellen Lynn, U.S. Geological Survey, April 11, 2019. 


\section{Distribution and Demography of Coastal Cactus Wrens (Campylorhynchus brunneicapillus) in Southern San Diego County, California-2020 Data Summary}

By Suellen Lynn and Barbara E. Kus

Data Series 1138 


\section{U.S. Geological Survey, Reston, Virginia: 2021}

For more information on the USGS - the Federal source for science about the Earth, its natural and living resources, natural hazards, and the environment—visit https://www.usgs.gov or call 1-888-ASK-USGS.

For an overview of USGS information products, including maps, imagery, and publications, visit https://store.usgs.gov/.

Any use of trade, firm, or product names is for descriptive purposes only and does not imply endorsement by the U.S. Government.

Although this information product, for the most part, is in the public domain, it also may contain copyrighted materials as noted in the text. Permission to reproduce copyrighted items must be secured from the copyright owner.

Suggested citation:

Lynn, S., and Kus, B.E., 2021, Distribution and demography of coastal cactus wrens (Campylorhynchus brunneicapillus) in southern San Diego County, California—2020 data summary: U.S. Geological Survey Data Series 1138, 12 p., https://doi.org/10.3133/ds1138.

Associated data for this publication:

Kus, B.E., and Lynn, S., 2021, Surveys and monitoring of coastal cactus wren in southern San Diego County: U.S. Geological Survey data release, https://doi.org/10.5066/F76H4FK5.

ISSN 2327-638X (online) 


\section{Acknowledgments}

The authors thank the biologists who assisted in data collection for this project:

Trevin Braun, Annabelle Bernabe, and Alex Houston, U.S. Geological Survey. We also thank the land managers, property owners, and other stakeholders who facilitated access to the survey plots, including but not limited to: Pete Famolaro (Sweetwater Authority), John Martin (San Diego National Wildlife Refuge), Debbie Lundy and Kira Haley (Helix Water District), Michael Galloway (California Department of Transportation), Troy Goodenough (San Diego Gas and Electric Company), Patricia Smith (City of Chula Vista), Brian Canaris (Otay Project Limited Partnership [LP]), Andrew Field (City of San Diego), Mary Neiz, Maryanne Vancio, Erica Mills, James Stowers, Megan Hamilton, Roger Covalt, Michael Verderber, Joshua Lambdin, Mika Shamada-Cirirelli, Lauren Raduc and David Collins (San Diego County Parks and Recreation), Tracie Nelson (California Department of Fish and Wildlife), Jason Forga and Emmanuel Gaviola (San Diego County Department of General Services), Pastor Dan Grant and Tylene Howarter (Skyline Church), and Cindy Dunn (City of San Diego Real Estate Assets Department, Airports Division). 



\section{Contents}

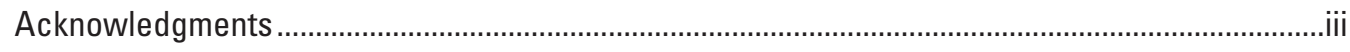

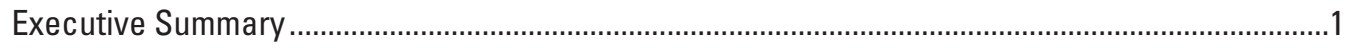

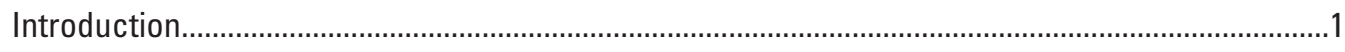

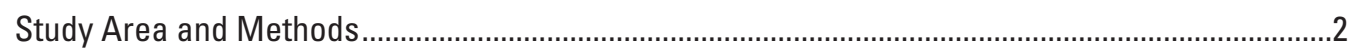

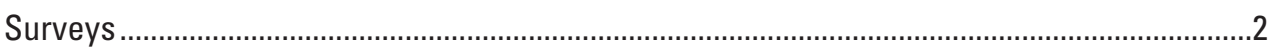

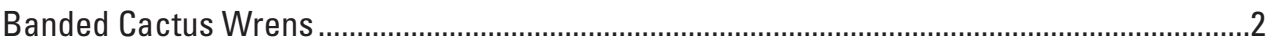

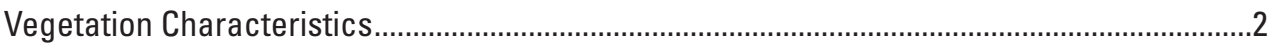

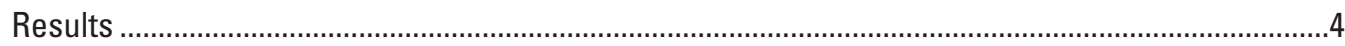

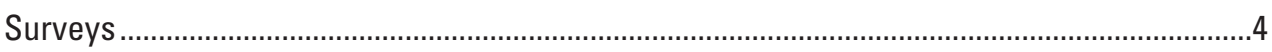

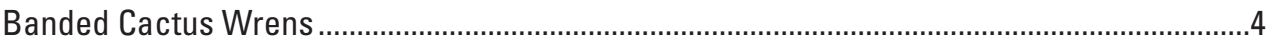

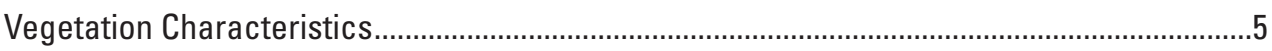

Summary

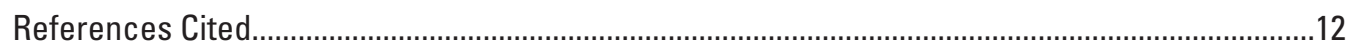

\section{Figures}

1. Map showing locations of Cactus Wren survey plots in southern San Diego County, California, 2020..

2. Graph showing number of survey plots that were occupied by Cactus Wrens by the percentage of cactus present that was dead, southern San Diego County, 2020 ....10

3. Graph showing number of survey plots that were occupied by Cactus Wrens by the percentage of cactus present that was unhealthy, southern San Diego County, 2020 .

4. Graph showing number of survey plots that were occupied by Cactus Wrens by the percentage of cactus present that was crowded or overtopped by vines or shrubs, southern San Diego County, 2020

5. Graph showing number of survey plots that were occupied by Cactus Wrens by the percent cover of non-native annual plants, southern San Diego County, 2020 


\section{Tables}

1. Number of plots surveyed and number occupied by Cactus Wrens by genetic cluster .4

2. Number and breeding status of Cactus Wren territories by genetic cluster .4

3. Location, number, and proportion of color-banded Cactus Wrens by genetic cluster in 2020 ..

4. Between year movement by adult Cactus Wrens detected in 2019 and 2020, southern San Diego County, California .....

5. Between year movement by first-year Cactus Wrens hatched in 2019 and detected again in 2020, southern San Diego County, California

6. Dominant vegetation cover types at Cactus Wren survey plots, southern San Diego County, 2020. Vegetation cover type codes developed by Holland (1986) and modified by Sawyer and others (2009)

7. Shrub species that were dominant or co-dominant at Cactus Wren survey plots in 2020, southern San Diego County, California...

8. Proportion of cactus that was dead at Cactus Wren survey plots in 2020, southern San Diego County, California

9. Proportion of cactus that was unhealthy at Cactus Wren survey plots in 2020, southern San Diego County, California

10. Proportion of cactus that was crowded or overtopped by vines and shrubs at Cactus Wren survey plots in 2020, southern San Diego County, California.

11. Proportion of non-native annual cover at Cactus Wren survey plots in 2020, southern San Diego County, California

\section{Conversion Factors}

International System of Units to Inch/Pound

\begin{tabular}{|c|c|c|}
\hline Multiply & By & To obtain \\
\hline \multicolumn{3}{|c|}{ Length } \\
\hline centimeter $(\mathrm{cm})$ & 0.3937 & inch (in.) \\
\hline meter (m) & 3.281 & foot $(\mathrm{ft})$ \\
\hline kilometer (km) & 0.6214 & mile (mi) \\
\hline kilometer (km) & 0.5400 & mile, nautical (nmi) \\
\hline meter $(\mathrm{m})$ & 1.094 & yard (yd) \\
\hline
\end{tabular}

\section{Datum}

Horizontal coordinate information is referenced to the World Geographic System of 1984 (WGS 84). 


\title{
Distribution and Demography of Coastal Cactus Wrens (Campylorhynchus brunneicapillus) in Southern San Diego County, California—2020 Data Summary
}

\author{
By Suellen Lynn and Barbara E. Kus
}

\section{Executive Summary}

Surveys for coastal Cactus Wren (Campylorhynchus brunneicapillus) were done in 378 established plots in southern San Diego County in 2020, encompassing three genetic clusters (Otay, Lake Jennings, and Sweetwater/ Encanto genetic clusters). Two surveys were completed at each plot between March 1 and July 31. Cactus Wrens were detected in 131 plots ( 35 percent of plots). This is a slight increase over the proportion of occupied plots in 2019. One hundred and nine Cactus Wren territories were detected across all survey plots in 2020, an increase from 83 in 2019. At least 85 percent of Cactus Wren territories were occupied by pairs, and 62 fledglings were observed in 2020.

There were 89 color-banded Cactus Wrens observed in 2020,84 of which we could identify to individual. Adults of known age ranged from 1 to at least 6 years old. Adult Cactus Wrens moved on average 0.2 kilometers $(\mathrm{km}$; maximum $3.8 \mathrm{~km}$ ) from their 2019 territories to their 2020 territories. Cactus Wrens that fledged in 2019 moved on average $1.2 \mathrm{~km}$ (maximum $9.9 \mathrm{~km}$ ) to their 2020 territories. No known-identity Cactus Wrens moved between genetic clusters from 2019 to 2020.

Vegetation at Cactus Wren plots typically was dominated by coastal sage scrub shrubs such as California sagebrush (Artemisia californica), lemonadeberry (Rhus integrifolia), California buckwheat (Eriogonum fasciculatum), and broom baccharis (Baccharis sarothroides). Very little dead or unhealthy cactus was observed within Cactus Wren survey plots. Thirty-eight percent of plots had at least 25 percent of the cactus crowded or overtopped by vines and shrubs. Non-native annual cover was greater than 25 percent at 35 percent of plots.

\section{Introduction}

The coastal Cactus Wren (Campylorhynchus brunneicapillus, wren) is a fragmentation-sensitive resident species in southern California requiring thickets of cholla
(Cylindropuntia spp.) or prickly pear cactus (Opuntia spp.) for nesting. Limited naturally by the patchy distribution of this habitat, Cactus Wren populations have become further fragmented in recent decades by urbanization, habitat degradation, and stochastic events such as wildfire (Solek and Szijj, 2004; Hamilton and others, 2020). As a result, Cactus Wren populations have been diminished in size and distribution and occur largely as islands in a matrix of generally unsuitable habitat.

Among the possible consequences of habitat fragmentation on Cactus Wren viability is genetic isolation, which can lead to loss of genetic variability and ability to adapt to changing environments (Barr and others, 2015). Although Cactus Wrens, like other birds, are mobile and can presumably fly long distances between patches (Preston and Kamada, 2012; Barr and others, 2012, 2013; Kamada and Preston, 2013), little is known about actual connectivity among populations in southern California. Juvenile dispersal, whereby young birds leave their natal territories and establish breeding territories of their own, is the key process by which genetic connectivity is achieved, yet this stage of the life history of birds is probably the most poorly understood.

In addition to isolation, population declines in part of the range have raised concerns regarding the capacity for long-term persistence of Cactus Wrens in San Diego County. Coastal Cactus Wren populations have declined in southern California over the last three decades (Preston and Kamada, 2012); however, in San Diego County, particularly steep declines have been detected recently in the southern part of the County, in the vicinity of Otay Valley. Cactus Wren territories on conserved lands in this region, which numbered 53 in 1992, declined to 14 in 2014 (The Nature Conservancy [TNC] and San Diego Management and Monitoring Program [SDMMP], 2015).

Although associated with long-term declines, neither fire nor development appear to be the primary factor responsible for the more recent and localized Otay Cactus Wren population decline. Recent multiple years of drought could have affected wren abundance by reducing arthropod food resources, which could lower fecundity and survival (Preston and Kamada, 2012). Annual precipitation has been less than 75 percent of average ( 21.5 centimeters [cm]) in half of the last 
20 years (2000-19), and precipitation was less than $11 \mathrm{~cm}$ in 5 of those years. In 2014, an extreme drought year, productivity was exceptionally low, with only 3 fledglings observed during surveys of a population occupying 14 territories in the Otay region (The Nature Conservancy and San Diego Management and Monitoring Program, 2015).

Food availability for Cactus Wrens could be affected by annual precipitation and mediated by habitat quality, as characterized by the composition and cover of native and non-native plant species, amount of bare ground, and microsite characteristics such as soils, slope and aspect. Poor habitat quality could exacerbate food limitation during drought years; thus, improving habitat quality through management could increase food availability and enhance wren productivity and survival. Developing management strategies to increase the stability of wren populations in years with low rainfall could be of particular importance if droughts become more frequent, intense and prolonged in the future, as predicted by climate change models.

The goal of the 2020 Cactus Wren effort was to perform surveys to assess the population status, banding status, breeding status, nesting status, and habitat attributes of Cactus Wrens in southern San Diego County. This report is the annual update to surveys that have been completed since 2015 (2015, 2017, 2018, and 2019; Kus and Lynn, 2021).

\section{Study Area and Methods}

\section{Surveys}

Survey plots were established throughout San Diego County by the U.S. Fish and Wildlife Service in 2011. We selected a subset of these plots in southern San Diego County within Management Units 3 and 4 that included three genetic clusters: (1) Otay genetic cluster, (2) Lake Jennings genetic cluster, and (3) Sweetwater/Encanto genetic cluster (Barr and others, 2015; fig. 1).

Each survey plot was visited twice during a survey year, once between March 1 and May 31 and once between June 1 and July 31. Plots were scanned for Cactus Wrens and Cactus Wren nests on arrival, and if wrens were not immediately detected, a Cactus Wren song was broadcast for 15-30 seconds to elicit response. If no wrens were detected, plots were then carefully traversed, looking for wrens or wren nests, periodically broadcasting the wren song for up to 20 minutes. In addition to recording presence or absence of Cactus Wrens, observers attempted to count all Cactus Wrens using the plot, determine their age, resight legs to record color-band combinations, and record presence of active nests. A Global Positioning System (GPS) point was collected where Cactus Wrens were located, and if no wrens were observed, GPS points were collected at confirmed Cactus Wren nests.
Cactus Wren territories often included all or parts of multiple survey plots. Therefore, occupancy of survey plots alone likely overestimated the actual number of Cactus Wrens in the survey areas. To arrive at a more standard population count, surveyors observed the behavior of wrens during surveys to determine the actual number of Cactus Wrens using a block of survey plots. Population parameters, including number of wrens, age, breeding status (whether or not the Cactus Wrens were paired), evidence of breeding (nests or fledglings observed), and color-band status were compiled by territory rather than by survey plot.

\section{Banded Cactus Wrens}

As part of nest monitoring activities completed in 2015 through 2019, in a separate project (Kus and Lynn, 2021), we banded adult and nestling wrens with a combination of colored leg bands that were unique to each individual. Adults were captured opportunistically at monitored territories by using mist nets and song playback. All nestlings from accessible nests in monitored territories were banded. In 2020, we attempted to resight all Cactus Wrens at survey plots to identify individuals based on color-band combinations. When bands were missing or observations were unclear, we returned on non-survey days to obtain photographs using a Canon 7D Mark II Digital Single Lens Reflex camera with Canon 100-400 F4-F5.6 zoom lens. Photographs were useful in determining fine color differences (faded bands) or reading numbers on metal bands. Color-band resighting data were used to determine age and document movement from banding sites.

Cactus Wrens do not exhibit obvious sexual dimorphism when observed under normal field conditions. Gender typically is determined by specific behavioral cues (position during copulation, incubation only by female) or morphology when the bird is in the hand (females have brood patches, males have cloacal protuberances). Gender is not determinable for nestlings without genetic analysis. If none of these cues were observed, we assigned an adult as "male" if it sang or called more frequently or was more visually obvious (potentially advertising territory boundaries), although females can also exhibit these behaviors. As a result, we did not have a large sample of confirmed gender adults and therefore did not attempt gender-related analyses of survivorship or movements except as general summaries.

\section{Vegetation Characteristics}

During the first survey, observers noted habitat characteristics at each plot. These data included dominant and co-dominant tree or shrub species, presence or absence of Mexican/blue elderberry (elderberry; Sambucus nigra, present at many Cactus Wren territories in coastal southern California and thought to provide important resources for wrens, K. Preston, oral commun., 2015), the percent of cactus overtopped or crowded by shrubs, the percent of cactus that 


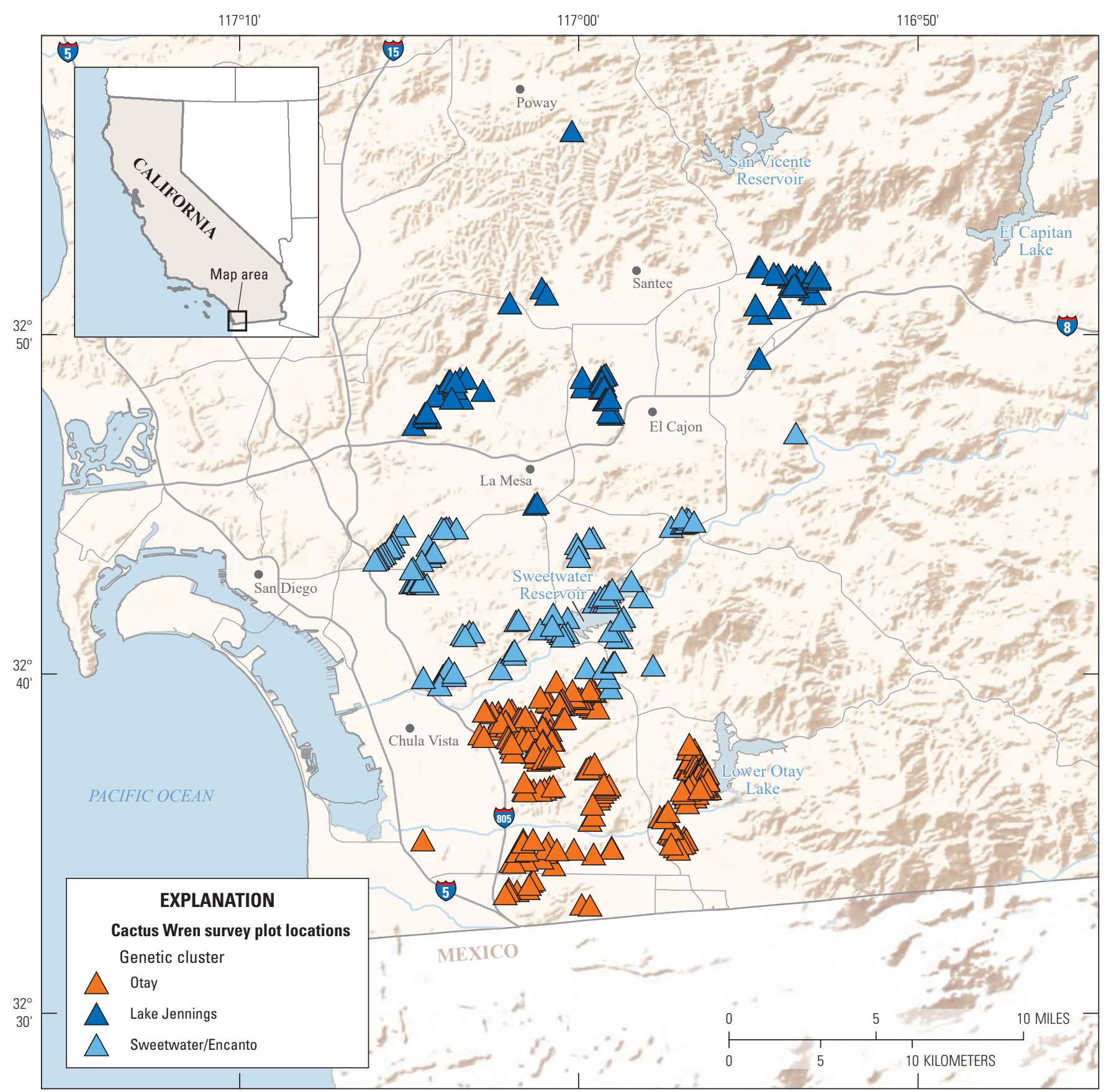

Map image is the intellectual property of Esri and is used herein under license. Copyright (c) 2020 Esri and its licensors. All rights reserved.

Figure 1. Locations of Cactus Wren survey plots in southern San Diego County, California, 2020.

was dead, the percent of cactus that was unhealthy, and the percent of the plot that was covered by non-native annual plant species. General vegetation type (Holland, 1986 modified by Sawyer and others, 2009) for each plot was assigned by overlaying San Diego vegetation type maps (SanGIS, 2017) over the survey plots using ArcMAP (Environmental Systems Research Institute, 2019).
We used chi-square analyses to determine if Cactus Wrens were more likely to occupy plots that were classified as containing 5 percent or less of each vegetation characteristic versus more than 5 percent of that vegetation characteristic. We hypothesized that more Cactus Wrens would occupy plots that contained (1) 5 percent or less dead cactus, (2) 5 percent or less unhealthy cactus, (3) 5 percent or less cactus that was crowded or overtopped by vines and shrubs, and (4) 5 percent or less non-native annual grass and forb cover. We 
also used chi-square analyses to determine if Cactus Wrens were more likely to occupy plots that contained elderberry than those that did not contain elderberry. We hypothesized that Cactus Wrens would select plots that contained elderberry. For these one-tailed tests, we considered $P<0.05$ to be a significant result.

\section{Results}

\section{Surveys}

We surveyed 378 plots for Cactus Wrens in 2020 (table 1; Kus and Lynn, 2021). Cactus Wrens were detected at 35 percent of all plots (131/378), 25 percent of Otay plots (53/209), and 46 percent of San Diego plots (78/169). We observed 109 Cactus Wren territories throughout all survey plots (table 2). We determined that Cactus Wrens in 93 territories ( 85 percent) were paired and we could not determine the paired status of 16 territories. We observed 62 fledglings during surveys.

\section{Banded Cactus Wrens}

We were able to observe 203 adult Cactus Wrens (110 males, 100 percent of all males, and 89 females, 96 percent of all females) on surveys well enough to determine banding status in 2020, although not all banded wrens were observed well enough to conclusively identify the individual. Eighty-nine wrens had been banded prior to the 2020 breeding season (table 3). One male, three females, and one wren of unknown sex could not be identified because resights were inconclusive. Therefore, we were able to identify 84 wrens that had unique color-band combinations in 2020 (Kus and Lynn, 2021). Adult birds of known age ranged from 1 to at least 6 years old. Thirty-seven percent of adult banded birds were 1-year old in 2020.

Resighting banded birds allowed us to identify individuals that remained in the same territory they used in the previous year or moved to a different location. There were 44 adults ( 34 males and 10 females) that were identified at territories in 2019 that were detected again in 2020 (table 4). Of these 44 birds, 35 ( 27 males and 8 females) remained in the same breeding territory in 2020 that they occupied in 2019 (within 100 meters [m]). Four males moved to a neighboring territory (more than $100 \mathrm{~m}$ but less than $300 \mathrm{~m}$ from their 2019 territory). Four Cactus Wrens (two males and two females) moved more than $300 \mathrm{~m}$ from their 2019 territory but stayed within their 2019 general survey location. One male Cactus Wren moved $3.8 \mathrm{~km}$ from his 2019 breeding territory at Johnson Canyon to his 2020 breeding territory at Brown Field but remained within the Otay genetic cluster. On average, adult Cactus Wren moved $0.2 \pm 0.6 \mathrm{~km}$ between 2019 and 2020 (range 0.0-3.8 km; males $0.2 \pm 0.6 \mathrm{~km}$, range $0.0-3.8 \mathrm{~km}$; females $0.2 \pm 0.3 \mathrm{~km}$, range $0.0-0.9 \mathrm{~km}$ ). We did not detect adult movement between genetic clusters from 2019 to 2020 .

Of the 114 Cactus Wrens that were banded as nestlings in 2019, 31 were resighted in 2020 in known territories (27 percent; 19 males, 9 females, and 3 of unknown sex; table 5). The three birds of unknown sex were detected at their natal territories in early April 2020 before they had dispersed

Table 1. Number of plots surveyed and number occupied by Cactus Wrens by genetic cluster.

[Survey 1: April 1 through May 31, 2020. Survey 2: June 1 through July 31, 2020]

\begin{tabular}{lccccc}
\hline \multirow{2}{*}{ Genetic cluster } & \multicolumn{5}{c}{ Number of plots } \\
\cline { 2 - 6 } & Surveyed & $\begin{array}{c}\text { Occupied } \\
\text { survey 1 }\end{array}$ & $\begin{array}{c}\text { Occupied } \\
\text { survey 2 }\end{array}$ & $\begin{array}{c}\text { Total oc- } \\
\text { cupied }\end{array}$ & $\begin{array}{c}\text { Percentage } \\
\text { occupied }\end{array}$ \\
\hline Otay & 209 & 45 & 46 & 53 & 25 \\
Lake Jennings & 69 & 25 & 22 & 29 & 42 \\
Sweetwater/ & 100 & 41 & 42 & 49 & 49 \\
$\quad$ Encanto & $\mathbf{3 7 8}$ & $\mathbf{1 1 1}$ & $\mathbf{1 1 0}$ & $\mathbf{1 3 1}$ & $\mathbf{3 5}$ \\
\hline Total & & & & & \\
\hline
\end{tabular}

Table 2. Number and breeding status of Cactus Wren territories by genetic cluster.

\begin{tabular}{lccccc}
\hline \multirow{2}{*}{ Genetic cluster } & \multicolumn{2}{c}{ Breeding status } & \multirow{2}{*}{ Total territories } & Number of fledglings \\
\cline { 2 - 3 } & Paired & Unknown & & 35 \\
\hline Otay & 38 & 7 & 45 & 14 \\
Lake Jennings & 20 & 3 & 23 & 13 \\
Sweetwater/Encanto & 35 & 6 & 41 & $\mathbf{6 2}$ \\
\hline Total & $\mathbf{9 3}$ & $\mathbf{1 6}$ & $\mathbf{1 0 9}$ & \\
\hline
\end{tabular}


to their breeding territories. They were not detected after early April. The average distance that first-year wrens moved from their natal territories to their first breeding territories was $1.2 \pm 2.0 \mathrm{~km}$ (range $0.0-9.9 \mathrm{~km}$; males moved $1.3 \pm 2.4 \mathrm{~km}$, range $0.0-9.9 \mathrm{~km}$; females moved $1.0 \pm 1.0 \mathrm{~km}$, range $0.3-3.4 \mathrm{~km}$ ). We did not detect first-year wren movement between genetic clusters from 2019 to 2020 .

\section{Vegetation Characteristics}

Vegetation characteristics were recorded at all 378 Cactus Wren survey plots in 2020. The most prevalent general vegetation type was Diegan coastal sage scrub ( 73 percent of plots; table 6). Land cover heavily affected by human presences (urban/developed, disturbed, and extensive agriculture) predominated at 11 percent of survey plots. Valley and foothill grassland and maritime succulent scrub were dominant at 6 percent and 5 percent of plots, respectively. The remaining vegetation cover types (southern mixed chaparral, non-native grassland, and chaparral) dominated fewer than 5 percent of plots.

Common coastal sage scrub shrub species were the dominant species at most of the plots, including California sagebrush (Artemisia californica), lemonadeberry (Rhus integrifolia), California buckwheat (Eriogonum fasciculatum), and broom baccharis (Baccharis sarothroides; table 7).

Of the 378 survey plots, 91 (24 percent) contained elderberry. Cactus Wrens occupied a higher proportion of plots that contained elderberry (53 percent; 48/91) than plots that did not contain elderberry (28 percent; 83 of 287; chi square $=16.3, P<0.01$ ).

Less than 1 percent of cactus was dead at most Cactus Wren survey plots in 2020 (table 8), with another 32 percent of plots containing 1-5 percent of cactus that was dead. Eleven percent of plots contained more than five percent cactus that was dead. Cactus Wrens were more likely to occupy plots with 5-percent or less dead cactus than plots with more than 5 -percent dead cactus (chi square $=5.9$, two-tailed $P=0.02$; fig. 2).

At most of the Cactus Wren plots, 5-percent or less cactus showed signs of stress (table 9). Twenty-seven percent of plots contained between 5 and 25 percent unhealthy cactus. Approximately 8 percent of plots contained more than 25-percent cactus that was unhealthy. Cactus Wrens were more likely to occupy plots with 5-percent or less cactus that was unhealthy than plots with more than 5-percent unhealthy cactus (chi-square $=13.6$, two-tailed $P<0.01$; fig. 3 ).

At 59 percent of plots, vines and shrubs crowded or overtopped between 1 and 25 percent of the cactus (table 10). At 38 percent of plots, vines and shrubs crowded or
Table 3. Location, number, and proportion (within each genetic cluster) of color-banded Cactus Wrens by genetic cluster in 2020.

$[\geq$, greater than or equal to; - , not applicable]

\begin{tabular}{|c|c|c|c|c|}
\hline $\begin{array}{c}\text { Age in } \\
2020\end{array}$ & $\begin{array}{l}\text { Otay genetic } \\
\text { cluster }\end{array}$ & $\begin{array}{l}\text { Lake } \\
\text { Jennings ge- } \\
\text { netic cluster }\end{array}$ & $\begin{array}{c}\text { Sweetwater/ } \\
\text { Encanto genetic } \\
\text { cluster }\end{array}$ & Total \\
\hline \multicolumn{5}{|c|}{ Banded in 2015} \\
\hline$\geq 6$ yrs & - & $1(0.04)$ & $1(0.05)$ & $2(0.02)$ \\
\hline $5 \mathrm{yrs}$ & $2(0.05)$ & $1(0.04)$ & $1(0.05)$ & $4(0.05)$ \\
\hline \multicolumn{5}{|c|}{ Banded in 2016} \\
\hline $4 \mathrm{yrs}$ & $5(0.12)$ & $3(0.13)$ & $4(0.20)$ & $12(0.14)$ \\
\hline \multicolumn{5}{|c|}{ Banded in 2017} \\
\hline$\geq 4 \mathrm{yr}$ & - & $1(0.04)$ & - & $1(0.01)$ \\
\hline $3 \mathrm{yrs}$ & $11(0.27)$ & $5(0.22)$ & $5(0.25)$ & $21(0.25)$ \\
\hline \multicolumn{5}{|c|}{ Banded in 2018} \\
\hline$\geq 3 \mathrm{yrs}$ & $2(0.05)$ & $4(0.17)$ & $2(0.10)$ & $8(0.10)$ \\
\hline $2 \mathrm{yrs}$ & - & $1(0.04)$ & $4(0.20)$ & $5(0.06)$ \\
\hline \multicolumn{5}{|c|}{ Banded in 2019} \\
\hline $1 \mathrm{yr}$ & $21(0.51)$ & $7(0.30)$ & $3(0.15)$ & $31(0.37)$ \\
\hline \multicolumn{5}{|c|}{ Subtotal } \\
\hline - & 41 & 23 & 20 & 84 \\
\hline \multicolumn{5}{|c|}{ Unknown } \\
\hline$\geq 1 \mathrm{yr}$ & 5 & - & - & 5 \\
\hline \multicolumn{5}{|c|}{ Total } \\
\hline- & 46 & 23 & 20 & 89 \\
\hline
\end{tabular}

overtopped more than 25 percent of the cactus. Cactus Wrens were more likely to occupy plots with 5-percent or less cactus that was crowded or overtopped by vines and shrubs than plots that contained greater than 5-percent cactus that was crowded or overtopped by vines and shrubs (chi-square $=3.4$; two-tailed $P=0.06$; fig. 4).

Non-native annual grasses and forbs covered less than 25 percent of the Cactus Wren survey plots at 65 percent of plots (table 11). Twenty-one percent of plots had between 25 and 50 percent non-native annual cover and 14 percent of plots had greater than 50-percent non-native annual cover. There was no difference in Cactus Wren occupancy of plots with less than or equal to 5-percent non-native annual cover compared to plots with greater than 5-percent non-native cover (fig. 5). 
Table 4. Between year movement by adult Cactus Wrens detected in 2019 and 2020, southern San Diego County, California.

[Genetic cluster codes: Otay, Otay genetic cluster, LJ, Lake Jennings genetic cluster, SW-EN, Sweetwater/Encanto genetic cluster. Band combination codes: BKBK, plastic black; DBDB, plastic dark blue; DGDG, plastic dark green; Msi, metal silver numbered band; OROR, plastic orange; RERE, plastic red; WHWH, plastic white; YEYE, plastic yellow. Sex codes: F, female; M, male. Abbreviation: km, kilometer; - , unbanded]

\begin{tabular}{|c|c|c|c|c|c|c|}
\hline \multirow{2}{*}{$\begin{array}{l}\text { Last year } \\
\text { seen }\end{array}$} & \multicolumn{2}{|c|}{ Genetic cluster / territory } & \multirow{2}{*}{$\begin{array}{c}\text { Distance } \\
\text { moved (km) }\end{array}$} & \multicolumn{2}{|c|}{ Band combination } & \multirow{2}{*}{ Sex } \\
\hline & Previous year & 2020 & & Left leg & Right leg & \\
\hline 2019 & Otay / Joy & Otay / $155 \mathrm{c}$ & 0.00 & Msi & YEYE & M \\
\hline 2019 & SW-EN / Sonia & SW-EN / 67c & 0.01 & DBDB Msi & DGDG RERE & $\mathrm{M}$ \\
\hline 2019 & SW-EN / Sonia & SW-EN / 67c & 0.01 & DGDG Msi & DGDG WHWH & $\mathrm{F}$ \\
\hline 2019 & LJ / Laurel & $\mathrm{LJ} / 4 \mathrm{c}$ & 0.01 & OROR Msi & DBDB WHWH & $\mathrm{M}$ \\
\hline 2019 & SW-EN / Food & SW-EN / 254c & 0.01 & WHWH OROR & Msi & M \\
\hline 2019 & SW-EN / Kite & SW-EN / 249c & 0.01 & Msi & RERE & $\mathrm{M}$ \\
\hline 2019 & LJ / Helix & LJ / Helix & 0.02 & DGDG RERE & WHWH Msi & M \\
\hline 2019 & SW-EN / 348c & SW-EN / 348c & 0.02 & DGDG BKBK & RERE Msi & M \\
\hline 2019 & Otay / Sis & Otay / 120c & 0.02 & YEYE OROR & YEYE Msi & $\mathrm{M}$ \\
\hline 2019 & SW-EN / Jam & SW-EN / JAM & 0.02 & RERE Msi & WHWH DBDB & M \\
\hline 2019 & SW-EN / Rice & SW-EN / Rice & 0.02 & WHWH & RERE Msi & M \\
\hline 2019 & $\mathrm{LJ} / 7 \mathrm{c}$ & $\mathrm{LJ} / 7 \mathrm{c}$ & 0.02 & YEYE Msi & WHWH & $\mathrm{F}$ \\
\hline 2019 & LJ / Hermit & $\mathrm{LJ} / 34 \mathrm{c}$ & 0.02 & OROR & DBDB Msi & M \\
\hline 2019 & LJ / Hermit & $\mathrm{LJ} / 34 \mathrm{c}$ & 0.02 & OROR Msi & DGDG & $\mathrm{F}$ \\
\hline 2019 & LJ / Camper & $\mathrm{LJ} / 31 \mathrm{c}$ & 0.03 & OROR Msi & - & M \\
\hline 2019 & LJ / Camper & $\mathrm{LJ} / 31 \mathrm{c}$ & 0.03 & YEYE RERE & WHWH Msi & $\mathrm{F}$ \\
\hline 2019 & LJ / Sentry & $\mathrm{LJ} / 2 \mathrm{c}$ & 0.03 & DGDG Msi & YEYE DBDB & $\mathrm{F}$ \\
\hline 2019 & LJ / Sentry & $\mathrm{LJ} / 2 \mathrm{c}$ & 0.03 & OROR & DGDG Msi & M \\
\hline 2019 & Otay / Resist & Otay / 274c & 0.03 & DGDG Msi & - & $\mathrm{F}$ \\
\hline 2019 & Otay / Resist & Otay / 274c & 0.03 & OROR & YEYE Msi & M \\
\hline 2019 & SW-EN / Rave 3 & SW-EN / 64c02 & 0.03 & DGDG DGDG & OROR Msi & M \\
\hline 2019 & $\mathrm{LJ} / \mathrm{EC} 02 \mathrm{c}$ & $\mathrm{LJ} / \mathrm{EC} 02 \mathrm{c}$ & 0.03 & YEYE Msi & RERE DGDG & M \\
\hline 2019 & Otay / $114 c$ & Otay / $114 c$ & 0.03 & OROR Msi & DGDG RERE & $\mathrm{F}$ \\
\hline 2019 & SW-EN / Tolstoy & SW-EN / 65c & 0.03 & YEYE WHWH & BKBK Msi & M \\
\hline 2019 & SW-EN / Best & SW-EN / 69c & 0.04 & Msi & RERE RERE & M \\
\hline 2019 & Otay / Condo & Otay / 276c & 0.05 & RERE WHWH & DBDB Msi & M \\
\hline 2019 & $\mathrm{LJ} / 566 \mathrm{c}$ & $\mathrm{LJ} / 566 \mathrm{c}$ & 0.05 & YEYE BKBK & DBDB Msi & M \\
\hline 2019 & Otay / Inhale & Otay / 276Ac & 0.06 & YEYE & OROR Msi & F \\
\hline 2019 & LJ / Zero & $\mathrm{LJ} / 0 \mathrm{c}$ & 0.06 & YEYE Msi & BKBK & M \\
\hline 2019 & Otay / 268c & Otay / 268c & 0.07 & RERE Msi & OROR WHWH & M \\
\hline 2019 & Otay / Good & Otay / $153 c$ & 0.07 & - & Msi & M \\
\hline 2019 & SW-EN / 251C & SW-EN / 250c & 0.08 & YEYE Msi & OROR DGDG & M \\
\hline 2019 & Otay / Late & Otay / 106c & 0.08 & RERE & Msi & M \\
\hline 2019 & SW-EN / 313c & SW-EN / 314c & 0.09 & OROR Msi & BKBK WHWH & M \\
\hline 2019 & SW-EN / Pioneer & SW-EN / 19c01 & 0.09 & RERE DGDG & WHWH Msi & M \\
\hline 2019 & $\mathrm{LJ} / \mathrm{SC} 01 \mathrm{c}$ & $\mathrm{LJ} / \mathrm{SC} 01 \mathrm{c}$ & 0.11 & Msi & BKBK YEYE & M \\
\hline 2019 & $\mathrm{LJ} / 283 \mathrm{c}$ & $\mathrm{LJ} / 283 \mathrm{c}$ & 0.12 & DBDB WHWH & OROR Msi & M \\
\hline 2019 & Otay / Jailbird & Otay / 278c & 0.12 & Msi & YEYE DGDG & M \\
\hline 2019 & Otay / Harrier & Otay / Owl & 0.19 & DGDG & DBDB Msi & M \\
\hline 2019 & SW-EN / 252C & SW-EN / 248c & 0.38 & WHWH YEYE & BKBK Msi & M \\
\hline
\end{tabular}


Table 4. Between year movement by adult Cactus Wrens detected in 2019 and 2020, southern San Diego County, California.Continued

[Genetic cluster codes: Otay, Otay genetic cluster, LJ, Lake Jennings genetic cluster, SW-EN, Sweetwater/Encanto genetic cluster. Band combination codes: BKBK, plastic black; DBDB, plastic dark blue; DGDG, plastic dark green; Msi, metal silver numbered band; OROR, plastic orange; RERE, plastic red; WHWH, plastic white; YEYE, plastic yellow. Sex codes: F, female; M, male. Abbreviation: km, kilometer; -, unbanded]

\begin{tabular}{|c|c|c|c|c|c|c|}
\hline \multirow{2}{*}{$\begin{array}{l}\text { Last year } \\
\text { seen }\end{array}$} & \multicolumn{2}{|c|}{ Genetic cluster / territory } & \multirow{2}{*}{$\begin{array}{c}\text { Distance } \\
\text { moved (km) }\end{array}$} & \multicolumn{2}{|c|}{ Band combination } & \multirow{2}{*}{ Sex } \\
\hline & Previous year & 2020 & & Left leg & Right leg & \\
\hline 2019 & Otay / Kim's & Otay / 115c & 0.45 & DBDB YEYE & Msi & $\mathrm{M}$ \\
\hline 2019 & LJ / Tank & $\mathrm{LJ} / 31 \mathrm{ac}$ & 0.65 & OROR & Msi & $\mathrm{F}$ \\
\hline 2019 & SW-EN / 253C & SW-EN / 248c & 0.88 & DGDG RERE & Msi & $\mathrm{F}$ \\
\hline 2019 & Otay / Yucca & Otay / 686c & 3.82 & Msi & WHWH DGDG & $\mathrm{M}$ \\
\hline 2018 & Otay / JC01c & Otay / JC01c & 0.01 & OROR RERE & DGDG Msi & $\mathrm{M}$ \\
\hline 2018 & Otay / Yucca & Otay / 635c & 0.01 & DBDB Msi & DGDG YEYE & $\mathrm{F}$ \\
\hline 2018 & $\mathrm{LJ} / 580 \mathrm{c}$ & $\mathrm{LJ} / 580 \mathrm{c}$ & 0.03 & DBDB YEYE & DGDG Msi & $\mathrm{F}$ \\
\hline 2018 & Otay / Vulcan & Otay / VU01c & 0.10 & YEYE Msi & BKBK & $\mathrm{F}$ \\
\hline 2018 & Otay / Raven & Otay / Raven2 & 0.10 & DGDG DBDB & OROR Msi & $\mathrm{F}$ \\
\hline 2018 & SW-EN / Rave & SW-EN / 64c01c & 0.13 & BKBK Msi & BKBK & $\mathrm{F}$ \\
\hline 2018 & Otay / Vulcan 2 & Otay / 79c & 0.75 & DGDG Msi & WHWH DBDB & M \\
\hline 2017 & SW-EN / Food & SW-EN / 63c & 3.04 & DGDG & Msi & $\mathrm{F}$ \\
\hline 2017 & Otay / Late & Otay / 686c & 5.86 & BKBK DBDB & OROR Msi & $\mathrm{F}$ \\
\hline
\end{tabular}


Table 5. Between year movement by first-year Cactus Wrens hatched in 2019 and detected again in 2020, southern San Diego County, California.

[Genetic cluster codes: Otay, Otay genetic cluster, LJ, Lake Jennings genetic cluster, SW-EN, Sweetwater/Encanto genetic cluster. Band combination codes: BKBK, plastic black; DBDB, plastic dark blue; DGDG, plastic dark green; Msi, metal silver numbered band; OROR, plastic orange; RERE, plastic red; WHWH, plastic white; YEYE, plastic yellow. Sex codes: F, female; M, male; U, unknown. Abbreviation: km, kilometer]

\begin{tabular}{|c|c|c|c|c|c|}
\hline \multicolumn{2}{|c|}{ Genetic cluster / territory } & \multirow{2}{*}{ Distance moved (km) } & \multicolumn{2}{|c|}{ Band combination } & \multirow{2}{*}{ Sex } \\
\hline 2019 & 2020 & & Left leg & Right leg & \\
\hline LJ / Ladder & $\mathrm{LJ} / 31 \mathrm{ac}$ & 0.01 & OROR Msi & RERE WHWH & $\mathrm{M}$ \\
\hline Otay / Harrier & Otay / $634 \mathrm{c} 1$ & 0.06 & YEYE Msi & BKBK RERE & $\mathrm{U}$ \\
\hline Otay / Harrier & Otay / 634c & 0.06 & YEYE RERE & DBDB Msi & M \\
\hline Otay / Rave & Otay / Harrier1 & 0.06 & BKBK Msi & WHWH & $\mathrm{F}$ \\
\hline Otay / Good & Otay $/ 151 \mathrm{c}$ & 0.11 & WHWH Msi & BKBK DBDB & M \\
\hline Otay / Yucca & Otay / $634 \mathrm{c} 1$ & 0.14 & OROR WHWH & DGDG Msi & $\mathrm{U}$ \\
\hline Otay / Harrier & Otay / 635c & 0.14 & BKBK Msi & WHWH WHWH & M \\
\hline Otay / Yucca & Otay / Raven & 0.21 & WHWH DBDB & RERE Msi & $\mathrm{M}$ \\
\hline SW-EN / Tolstoy & SW-EN / 64c01 & 0.21 & OROR OROR & BKBK Msi & $\mathrm{M}$ \\
\hline Otay / Neat & Otay $/ 117 \mathrm{c}$ & 0.22 & DGDG DGDG & Msi & $\mathrm{M}$ \\
\hline Otay / Sis & Otay / 119c & 0.26 & BKBK DBDB & DGDG Msi & M \\
\hline Otay / Jailbird & Otay / 279c & 0.29 & WHWH WHWH & BKBK Msi & M \\
\hline LJ / Tank & $\mathrm{LJ} / 299 \mathrm{c}$ & 0.32 & WHWH Msi & BKBK WHWH & $\mathrm{M}$ \\
\hline LJ / Ladder & $\mathrm{LJ} / 299 \mathrm{c}$ & 0.34 & RERE Msi & DGDG BKBK & $\mathrm{F}$ \\
\hline Otay / Sis & Otay / Kims & 0.36 & DBDB Msi & DBDB WHWH & $\mathrm{F}$ \\
\hline Otay / Harrier & Otay / Raven2 & 0.42 & DGDG YEYE & BKBK Msi & M \\
\hline Otay / Good & Otay / 138c & 0.43 & RERE RERE & RERE Msi & $\mathrm{M}$ \\
\hline LJ / Ladder & $\mathrm{LJ} / 298 \mathrm{c}$ & 0.59 & BKBK BKBK & YEYE Msi & $\mathrm{F}$ \\
\hline Otay / Good & Otay / 142c & 0.64 & WHWH BKBK & DBDB Msi & M \\
\hline LJ / Camper & LJ / Helix & 0.67 & WHWH WHWH & YEYE Msi & $\mathrm{F}$ \\
\hline Otay / Late & Otay / $115 \mathrm{c}$ & 0.70 & Msi & YEYE YEYE & $\mathrm{F}$ \\
\hline Otay / Good & Otay / 117c & 0.71 & BKBK Msi & WHWH BKBK & $\mathrm{F}$ \\
\hline LJ / Ladder & $\mathrm{LJ} / 0 \mathrm{c}$ & 0.86 & BKBK & DBDB Msi & $\mathrm{F}$ \\
\hline SW-EN / Food & SW-EN / 19c02 & 0.98 & DBDB Msi & WHWH WHWH & $\mathrm{F}$ \\
\hline Otay / Sis & Otay / CSC02c & 0.99 & WHWH Msi & YEYE BKBK & M \\
\hline Otay / Inhale & Otay / 271c & 1.48 & YEYE Msi & WHWH WHWH & M \\
\hline SW-EN / Food & SW-EN / 252c & 1.50 & YEYE YEYE & RERE Msi & M \\
\hline LJ / Camper & $\mathrm{LJ} / 7 \mathrm{c}$ & 2.64 & OROR Msi & RERE BKBK & M \\
\hline Otay / Sis & Otay / 279c & 3.37 & WHWH WHWH & WHWH Msi & $\mathrm{F}$ \\
\hline Otay / Harrier & Otay / 143c & 4.43 & RERE BKBK & OROR Msi & M \\
\hline Otay / Kim`s & Otay / $288 \mathrm{c}$ & 9.93 & DGDG BKBK & WHWH Msi & $\mathrm{M}$ \\
\hline
\end{tabular}


Table 6. Dominant vegetation cover types at Cactus Wren survey plots, southern San Diego County, 2020. Vegetation cover type codes developed by Holland (1986) and modified by Sawyer and others (2009).

[Proportion of plots of that vegetation type within the cluster are in parentheses. Abbreviation: - , not present]

\begin{tabular}{|c|c|c|c|c|}
\hline \multirow[b]{2}{*}{$\begin{array}{l}\text { Predominant vegetation cover } \\
\text { type }\end{array}$} & \multicolumn{3}{|c|}{ Number of plots } & \multirow[b]{2}{*}{ Total } \\
\hline & $\begin{array}{l}\text { Otay genetic } \\
\text { cluster }\end{array}$ & $\begin{array}{l}\text { Lake Jennings } \\
\text { genetic } \\
\text { cluster }\end{array}$ & $\begin{array}{c}\text { Sweetwater/ } \\
\text { Encanto genetic } \\
\text { cluster }\end{array}$ & \\
\hline Diegan coastal sage scrub & $147(0.70)$ & $55(0.80)$ & $74(0.74)$ & $276(0.73)$ \\
\hline Urban/developed & $8(0.04)$ & $11(0.16)$ & $7(0.07)$ & $26(0.07)$ \\
\hline Valley and foothill grassland & $11(0.05)$ & $1(0.01)$ & $11(0.11)$ & $23(0.06)$ \\
\hline Maritime succulent scrub & $20(0.10)$ & - & - & $20(0.05)$ \\
\hline Southern mixed chaparral & $12(0.06)$ & - & - & $12(0.03)$ \\
\hline Disturbed habitat & $3(0.01)$ & $1(0.01)$ & $6(0.06)$ & $10(0.03)$ \\
\hline Extensive agriculture & $6(0.03)$ & - & - & $6(0.02)$ \\
\hline Non-native grassland & $2(0.01)$ & - & $2(0.02)$ & $4(0.01)$ \\
\hline Chaparral & - & $1(0.01)$ & - & $1(0.00)$ \\
\hline Total & 209 & 69 & 100 & 378 \\
\hline
\end{tabular}

Table 7. Shrub species that were dominant or co-dominant at Cactus Wren survey plots in 2020, southern San Diego County, California.

[Proportion of plots containing that plant species within the genetic cluster are in parentheses. A plot may have more than one co-dominant plant species so proportions do not add to -1. Abbreviation: - , not present]

\begin{tabular}{|c|c|c|c|c|}
\hline \multirow[b]{2}{*}{ Dominant shrub species } & \multicolumn{3}{|c|}{ Number of plots } & \multirow[b]{2}{*}{ Total } \\
\hline & $\begin{array}{l}\text { Otay genetic } \\
\text { cluster }\end{array}$ & $\begin{array}{l}\text { Lake } \\
\text { Jennings ge- } \\
\text { netic cluster }\end{array}$ & $\begin{array}{c}\text { Sweetwater/ } \\
\text { Encanto genetic } \\
\text { cluster }\end{array}$ & \\
\hline California sagebrush & $126(0.60)$ & $28(0.41)$ & $65(0.65)$ & $219(0.58)$ \\
\hline Lemonadeberry & $71(0.34)$ & $13(0.19)$ & $21(0.21)$ & $105(0.28)$ \\
\hline California buckwheat & $43(0.21)$ & $16(0.23)$ & $15(0.15)$ & $74(0.20)$ \\
\hline Broom baccharis & $3(0.01)$ & $26(0.38)$ & $11(0.11)$ & $40(0.11)$ \\
\hline Jojoba (Simmondsia chinensis) & $44(0.21)$ & - & $14(0.14)$ & $58(0.15)$ \\
\hline $\begin{array}{l}\text { San Diego sunflower (Bahiopsis } \\
\text { laciniata) }\end{array}$ & $35(0.17)$ & $4(0.06)$ & $16(0.16)$ & $55(0.15)$ \\
\hline Laurel sumac (Malosma laurina) & $2(0.01)$ & $20(0.29)$ & $8(0.08)$ & $30(0.08)$ \\
\hline Black mustard (Brassica nigra) & $1(0.00)$ & $5(0.07)$ & $5(0.05)$ & $11(0.03)$ \\
\hline $\begin{array}{l}\text { California sunflower (Encelia } \\
\text { californica) }\end{array}$ & $7(0.03)$ & $1(0.01)$ & $2(0.02)$ & $10(0.03)$ \\
\hline Acacia spp. & $4(0.02)$ & - & - & $4(0.01)$ \\
\hline $\begin{array}{l}\text { Western ragweed (Ambrosia } \\
\text { psilostachya) }\end{array}$ & $3(0.01)$ & - & - & $3(0.01)$ \\
\hline Black sage (Salvia mellifera) & - & $3(0.04)$ & $1(0.01)$ & $4(0.01)$ \\
\hline Mexican/blue elderberry & - & $1(0.01)$ & - & $1(0.00)$ \\
\hline Other $^{1}$ & $1(0.00)$ & - & - & $1(0.00)$ \\
\hline
\end{tabular}

${ }^{1}$ Entire plot had been burned and shrubs were unidentifiable. 
Table 8. Proportion of cactus that was dead at Cactus Wren survey plots in 2020, southern San Diego County, California.

$[-$, not applicable; $<$, less than; > greater than $]$

\begin{tabular}{|c|c|c|c|c|}
\hline \multirow[b]{2}{*}{ Percent cover } & \multicolumn{3}{|c|}{ Proportion of plots } & \multirow[b]{2}{*}{ Total } \\
\hline & $\begin{array}{l}\text { Otay genetic } \\
\text { cluster }\end{array}$ & $\begin{array}{l}\text { Lake Jennings } \\
\text { genetic cluster }\end{array}$ & $\begin{array}{c}\text { Sweetwater/Encanto } \\
\text { genetic cluster }\end{array}$ & \\
\hline 0 & 0.06 & - & 0.05 & 0.04 \\
\hline$<1$ & 0.45 & 0.51 & 0.68 & 0.52 \\
\hline $1-5$ & 0.35 & 0.41 & 0.21 & 0.32 \\
\hline$>5-25$ & 0.11 & 0.09 & 0.05 & 0.09 \\
\hline$>25-50$ & 0.00 & - & 0.01 & 0.01 \\
\hline$>50-75$ & 0.02 & - & - & 0.01 \\
\hline$>75$ & - & - & - & - \\
\hline Total plots & 209 & 69 & 100 & 378 \\
\hline
\end{tabular}

Table 9. Proportion of cactus that was unhealthy at Cactus Wren survey plots in 2020, southern San Diego County, California.

$[-$, not applicable; $<$, less than; > greater than $]$

\begin{tabular}{lcccc}
\hline \multirow{2}{*}{ Percent cover } & \multicolumn{3}{c}{ Proportion of plots } \\
\cline { 2 - 4 } & $\begin{array}{c}\text { Otay genetic } \\
\text { cluster }\end{array}$ & $\begin{array}{c}\text { Lake Jennings } \\
\text { genetic cluster }\end{array}$ & $\begin{array}{c}\text { Sweetwater/Encanto } \\
\text { genetic cluster }\end{array}$ & Total \\
\hline 0 & - & - & 0.01 & 0.00 \\
$<1$ & 0.24 & 0.25 & 0.16 & 0.22 \\
$1-5$ & 0.35 & 0.46 & 0.57 & 0.43 \\
$>5-25$ & 0.30 & 0.26 & 0.21 & 0.27 \\
$>25-50$ & 0.08 & 0.03 & 0.04 & 0.06 \\
$>50-75$ & 0.02 & - & 0.01 & 0.02 \\
$>75$ & 0.00 & - & - & 0.00 \\
\hline Total plots & $\mathbf{2 0 9}$ & $\mathbf{6 9}$ & $\mathbf{1 0 0}$ & $\mathbf{3 7 8}$ \\
\hline
\end{tabular}

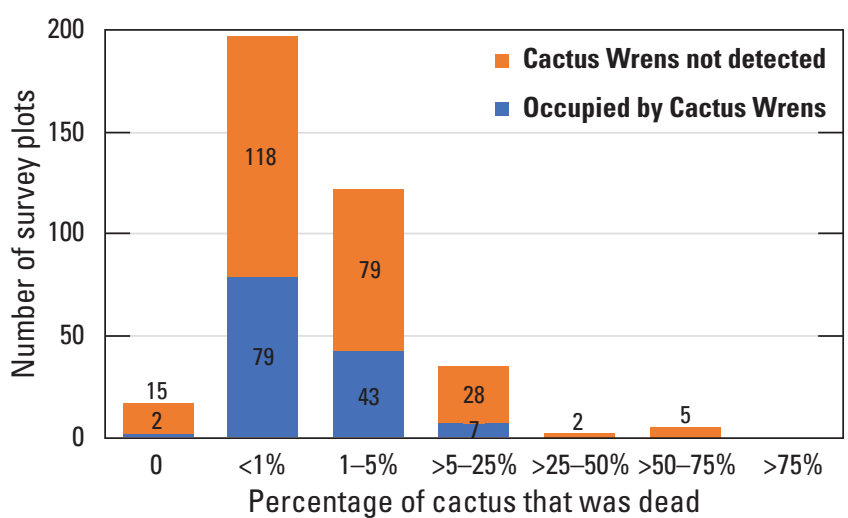

Figure 2. Number of survey plots that were occupied by Cactus Wrens by the percentage of cactus present that was dead, southern San Diego County, 2020.

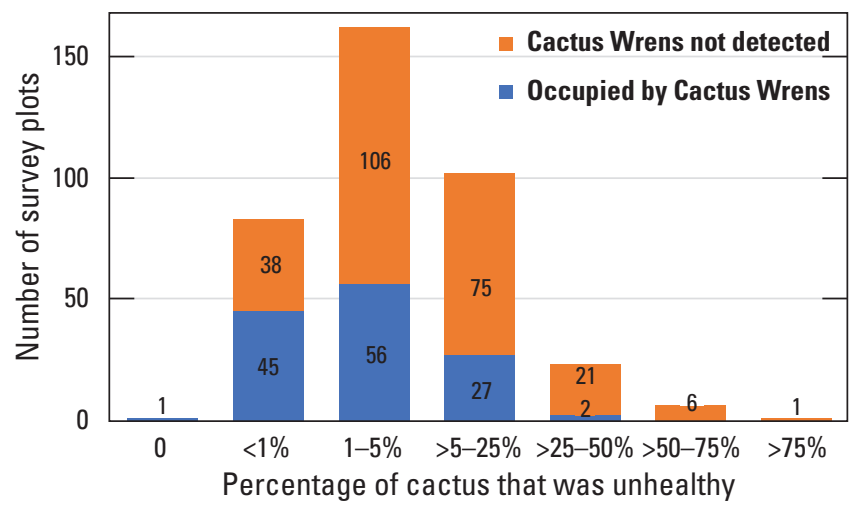

Figure 3. Number of survey plots that were occupied by Cactus Wrens by the percentage of cactus present that was unhealthy, southern San Diego County, 2020. 
Table 10. Proportion of cactus that was crowded or overtopped by vines and shrubs at Cactus Wren survey plots in 2020, southern San Diego County, California.

[-, not applicable; $<$, less than; > greater than]

\begin{tabular}{lcccc}
\hline \multirow{2}{*}{ Percent cover } & \multicolumn{3}{c}{ Proportion of plots } \\
\cline { 2 - 4 } & $\begin{array}{c}\text { Otay genetic } \\
\text { cluster }\end{array}$ & $\begin{array}{c}\text { Lake Jennings } \\
\text { genetic cluster }\end{array}$ & $\begin{array}{c}\text { Sweetwater/Encanto } \\
\text { genetic cluster }\end{array}$ & Total \\
\hline 0 & 0.00 & - & 0.01 & 0.01 \\
$<1$ & 0.02 & 0.03 & 0.03 & 0.03 \\
$1-5$ & 0.11 & 0.28 & 0.27 & 0.19 \\
$>5-25$ & 0.34 & 0.39 & 0.54 & 0.40 \\
$>25-50$ & 0.28 & 0.25 & 0.10 & 0.22 \\
$>50-75$ & 0.17 & 0.06 & 0.05 & 0.12 \\
$>75$ & 0.07 & - & - & 0.04 \\
\hline Total plots & $\mathbf{2 0 9}$ & $\mathbf{6 9}$ & $\mathbf{1 0 0}$ & $\mathbf{3 7 8}$ \\
\hline
\end{tabular}

Table 11. Proportion of non-native annual cover at Cactus Wren survey plots in 2020, southern San Diego County, California.

$[-$, not applicable; $<$, less than; > greater than $]$

\begin{tabular}{lcccc}
\hline \multirow{2}{*}{ Percent cover } & \multicolumn{3}{c}{ Proportion of plots } \\
\cline { 2 - 4 } & $\begin{array}{c}\text { Otay genetic } \\
\text { cluster }\end{array}$ & $\begin{array}{c}\text { Lake Jennings ge- } \\
\text { netic cluster }\end{array}$ & $\begin{array}{c}\text { Sweetwater/Encanto } \\
\text { genetic cluster }\end{array}$ & Total \\
\hline 0 & - & 0.03 & 0.01 & 0.01 \\
$<1$ & 0.09 & 0.12 & 0.08 & 0.09 \\
$1-5$ & 0.17 & 0.28 & 0.29 & 0.22 \\
$>5-25$ & 0.38 & 0.25 & 0.28 & 0.33 \\
$>25-50$ & 0.22 & 0.23 & 0.20 & 0.21 \\
$>50-75$ & 0.10 & 0.07 & 0.08 & 0.09 \\
$>75$ & 0.05 & 0.03 & 0.06 & 0.05 \\
\hline Total plots & $\mathbf{2 0 9}$ & $\mathbf{6 9}$ & $\mathbf{1 0 0}$ & $\mathbf{3 7 8}$ \\
\hline
\end{tabular}

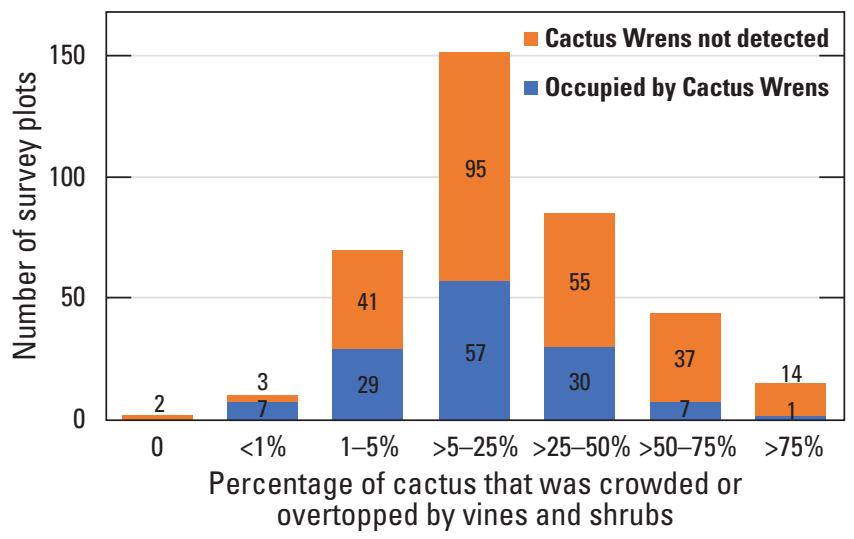

Figure 4. Number of survey plots that were occupied by Cactus Wrens by the percentage of cactus present that was crowded or overtopped by vines or shrubs, southern San Diego County, 2020.

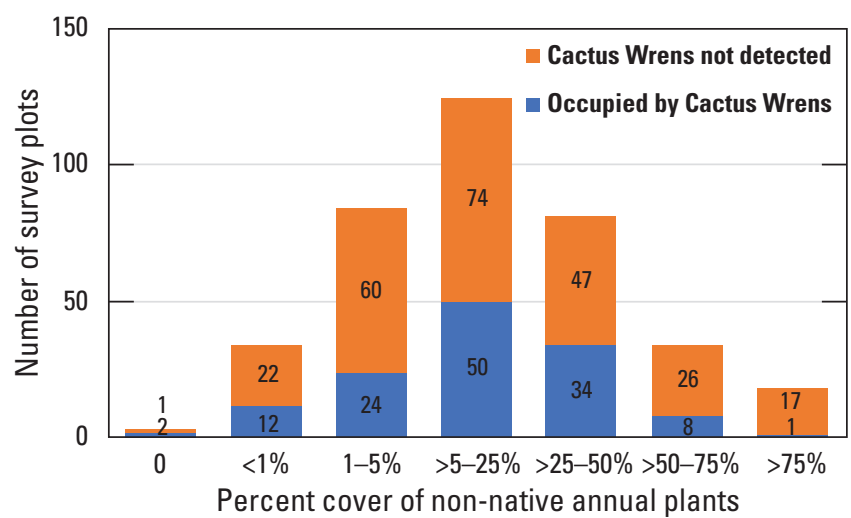

Figure 5. Number of survey plots that were occupied by Cactus Wrens by the percent cover of non-native annual plants, southern San Diego County, 2020. 


\section{Summary}

Cactus Wrens were detected in 35 percent of all survey plots in 2020, which is a slight increase over 33 percent of the same plots occupied in 2019 (Kus and Lynn, 2021). However, the number of Cactus Wren territories increased from 83 in 2019 to 109 in 2020 . The increase in number of territories was most dramatic in the Otay genetic cluster, where the number of territories from 2019 to 2020 increased from 25 to 45 . Most of the new territories in 2020 were established in Salt Creek (10 new territories) and Johnson Canyon (5 new territories). Although the number of territories increased by 80 percent in the Otay genetic cluster, the number of occupied survey plots in the Otay genetic cluster only increased by 6 percent (from 50 to 53), indicating that new territories were established near existing territories mostly within survey plots that were already occupied prior to 2020 .

We did not detect any movement of Cactus Wrens between genetic clusters between 2019 and 2020. Juvenile movements between 2019 and 2020 were greater than adult movements, although juveniles also did not appear to move far from their natal territories. With few exceptions, juveniles stayed within their natal canyons.

Elderberry has been suggested as an important resource for Cactus Wrens. Kristine Preston (U.S. Geological Survey, oral commun., 2015) noticed elderberry was present in many Cactus Wren territories in Orange County and suggested that it provided territorial advertising perches for adults, escape cover for fledglings, and could also be an important host for prey arthropods. Although most of the Cactus Wren plots did not contain elderberry, Cactus Wrens were more likely to occupy plots with elderberry than plots without elderberry in our study area. Cactus Wren habitat mostly was characterized by typical coastal sage scrub plant species but with a strong component of taller woody shrubs such as lemonadeberry and laurel sumac. The cactus in most survey plots was healthy, and Cactus Wrens preferentially selected survey plots with less dead or unhealthy cactus. Cactus that was crowded or overtopped by vines and shrubs was more prevalent, with 38 percent of plots having over 25 percent of the cactus affected, although Cactus Wrens preferentially selected plots with less shrub and vine crowding and overtopping. Non-native annual cover was greater than 25 percent at 35 percent of plots, and occupancy of survey plots by Cactus Wrens did not seem to be affected by the percentage of non-native annual cover.

\section{References Cited}

Barr, K.R., Vandergast, A.G., and Kus, B.E., 2012, Genetic connectivity in the Coastal Cactus Wren: Data summary report prepared for the San Diego Management and Monitoring Program, $30 \mathrm{p}$.
Barr, K.R., Vandergast, A.G., and Kus, B.E., 2013, Genetic structure in the Cactus Wren in coastal southern California: Data summary report prepared for the California Department of Fish and Wildlife, $27 \mathrm{p}$.

Barr, K.R., Kus, B.E., Preston, K.L., Howell, S., Perkins, E., and Vandergast, A.G., 2015, Habitat fragmentation in coastal southern California disrupts genetic connectivity in the Cactus Wren (Campylorhynchus brunneicapillus): Molecular Ecology, v. 24, no. 10, p. 2349-2363, https://doi.org/10.1111/mec.13176.

Environmental Systems Research Institute, 2019, ArcMAP version 10.7.1: Redlands, Calif., Environmental Systems Research Institute.

Hamilton, R.A., Proudfoot, G.A., Sherry, D.A., and Johnson, S.L., 2020, Cactus Wren (Campylorhynchus brunneicapillus), version 1.0, in Poole, A.F., ed., Birds of the world: Ithaca, NY, Cornell Lab of Ornithology, accessed October 14, 2020, at https://birdsofthe world.org/bow/species/cacwre/cur/introduction

Holland, R., 1986, Preliminary descriptions of the terrestrial natural communities of California - State of California: The Resources Agency, Department of Fish and Game, 156 p.

Kamada, D., and Preston, K., 2013, Nature reserve of Orange County-Coastal Cactus Wren dispersal and survival surveys, genetics, and parasite sampling, and arthropod foraging ecology in 2012: Annual report prepared in fulfillment of reporting requirements for the memorandum of understanding between Dana Kamada and the California Department of Fish and Wildlife, 92 p.

Kus, B.E., and Lynn, S., 2021, Surveys and monitoring of coastal cactus wren in southern San Diego County: U.S. Geological Survey data release, https://doi.org/10.5066/F76H4FK5.

Preston, K., and Kamada, D., 2012, Nature reserve of Orange County-Monitoring coastal Cactus Wren reproduction, dispersal and survival, 2009-2011-Final report prepared for California Department of Fish and Game: LAG no. 0982013, 85 p.

SanGIS, 2017, ECO_VEGETATION_CN, vegetation information in the San Diego region: San Diego County Department of Planning and Land Use, accessed October 6, 2020, at https://sangis.org/ download/index.html

Sawyer, J.O., Keeler-Wolf, T., and Evens, J.M., 2009, A manual of California vegetation $2 \mathrm{~d}$ ed.: Sacramento, California Native Plant Society, $1300 \mathrm{p}$.

Solek, C., and Szijj, L.J., 2004, Cactus Wren (Campylorhynchus brunneicapillus), in The coastal shrub and chaparral bird conservation plan-A strategy for protecting and managing coastal scrub and chaparral habitats and associated birds in California: California Partners in flight, accessed October 14, 2020, at http:/www.prbo.org/calpif/htmldocs/species/scrub/cactus wren.html.

The Nature Conservancy and San Diego Management and Monitoring Program, 2015, South San Diego County coastal Cactus Wren (Campylorhynchus brunneicapillus) habitat conservation and management plan: Prepared for San Diego Association of Governments, June 18, 2015, 37 p., https://sdmmp.com/upload/ projects/20160330_2357_194.pdf. 
For more information concerning the research in this report, contact the

Director, Western Ecological Research Center

U.S. Geological Survey

3020 State University Drive East

Sacramento, California, 95819

https://www.usgs.gov/centers/werc

Publishing support provided by the U.S. Geological Survey

Science Publishing Network, Sacramento Publishing Service Center 


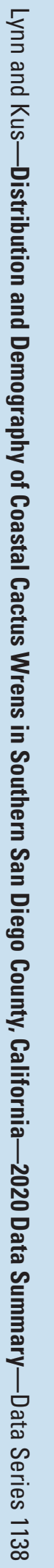

